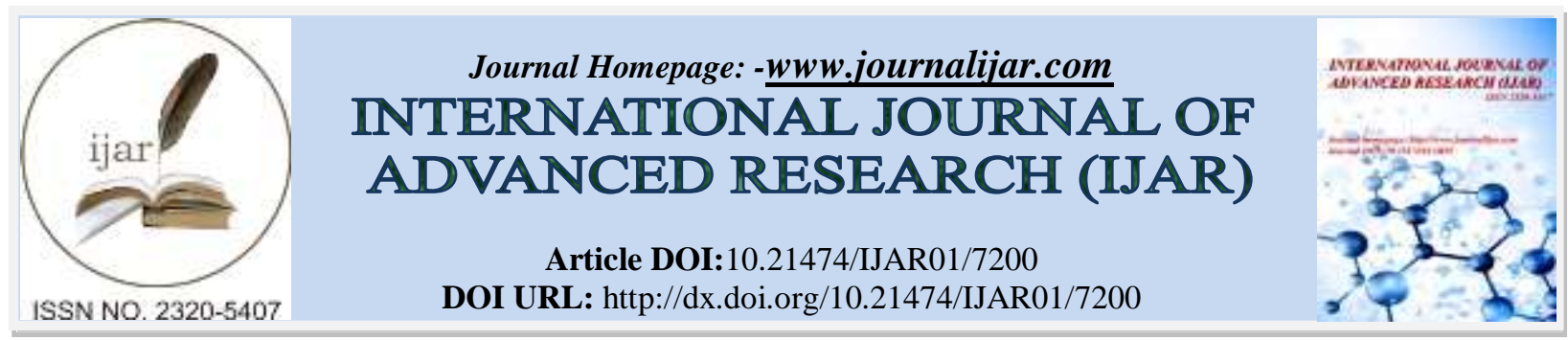

RESEARCH ARTICLE

\title{
SOCIO-DEMOGRAPHIC CORRELATES OF EMOTIONAL PROBLEMS AMONG SCHOOL CHILDREN IN PATHANAMTHITTA DISTRICT, KERALA.
}

\author{
Sheeja Mathew ${ }^{1}$ and Dr. Mridula Saikia Khanikor ${ }^{2}$. \\ 1. Associate Professor, MGM Muthoot College of Nursing, Kozhencherry, Pathanamthitta District, Kerala - 689641 \\ 2. Principal, Vinayaka Mission Sikkim College of Nursing, Gangtok.
}

\section{Manuscript Info}

Manuscript History

Received: 04 April 2018

Final Accepted: 06 May 2018

Published: June 2018

Keywords:-

Emotional problems; correlates; school children.

\begin{abstract}
Children and adolescence with emotional problems exhibit chronic and diverse academic, behavioural and/or medical difficulties that pose significant challenges for their education and treatment in schools. Life is challenging for children with emotional problems and it is also challenging for their families, their schools, and their teachers. The present study was conducted to identify the risk factors of emotional problems among school children. A descriptive correlational design was adopted for the study. Multistage cluster sampling technique was used in the study. The schools were selected randomly and 500 school children between the ages of $13-15$ years were selected using systematic random sampling technique. Baseline proforma and Paediatric Symptom Checklist-Youth Self Report were used to collect data. Data analysis was done using frequency, percentage Chi-square tests and logistic regressions. Results revealed that estimated prevalence rate of emotional problems was 22 per hundred cases among school children in Pathanamthitta District. The factors in the school and family situations were highly influencing the emotional state of school children. The study concludes that the estimated prevalence rate of emotional problems was high among school children at Pathanamthitta District and the parents, teachers and health departments need to recognize emotional problems as a serious health problem, and need to develop effective school mental health programs to increase the awareness thereby bringing a holistic development among the children, who will be the future of the nation.
\end{abstract}

Copy Right, IJAR, 2018,. All rights reserved.

\section{Introduction:-}

"Children are human beings to whom respect is due, superior to us by reason of their innocence and of the greater possibilities of their future."

\section{Maria Montessori}

"Children are the world's most valuable resource and its best hope for the future". A child's self-esteem affects every area of her existence, from friends she chooses, to how well she does academically in school, to what kind of job she gets. 
Children and adolescence with emotional problems exhibit chronic and diverse academic, behavioral and/or medical difficulties that pose significant challenges for their education and treatment in schools. Historically children with emotional problems have received fragmented inadequate interventions and services that often yielded unfavourable school and community outcomes. Numerous child/family, diagnostic and organizational barriers limit access to appropriate and effective treatment. ${ }^{1}$

Recent children's health surveys have documented a high prevalence of emotional, developmental, and behavioral problems among children. Data from the 2003 National Survey of Children's Health provide new insights into these problems and their association with family function and community participation. These issues have become a current focus of the World Health Organization. The results shows that the most commonly diagnosed problems among children 6-17 years of age were learning disabilities (11.5\%), attention-deficit/hyperactivity disorder (8.8\%), and behavioral problems (6.3\%); among preschoolers, speech problems (5.8\%) and developmental delay (3.2\%) were most common. One in 200 children was diagnosed with autism. In contrast, rates of parental concerns about emotional, developmental, or behavioral problems were much higher; for example, $41 \%$ of parents had concerns about learning difficulties and 36\% about depression or anxiety. Children with developmental problems had lower self-esteem, more depression and anxiety, more problems with learning, missed more school, and was less involved in sports and other community activities. Their families experienced more difficulty in the areas of childcare, employment, parent-child relationships, and caregiver burden. ${ }^{2}$

Children with emotional problems are one of the most under identified and untreated child clinical subpopulations. As indicated in the Surgeon General's report in US on mental health, one in five children display a diagnosable mental disorder each year and approximately 5\% have emotional problems that significantly impact their daily functioning at home and school. Children with emotional problems represent about 5\% of youth diagnosed with mental disorders and about $1 \%$ of those children diagnosed with emotional problems are treated. ${ }^{3}$

A population prevalence study of emotional and behavioral disorders was conducted among 1186 [6 -12] year old children in Minia, Egypt. Data was collected from teachers and parents using the Strengths and Difficulties Questionnaire with a 98 and 91\% response respectively. Prevalence of abnormal symptom scores is reported for both parents and teachers. Prevalence of probable psychiatric diagnoses was measured using the SDQ multiinformant algorithm. The prevalence of emotional and behavioral symptoms was high as reported by both parents and teachers (Abnormal total difficulties: teachers 34.7\% (95\% CI 32.0-37.5), parents 20.6\% (18.2-23.2). Abnormal prosocial scores: teachers $24.9 \%$ (22.5-27.5), parents $11.8 \%(9.9-13.9)$ ) but prevalence of probable psychiatric diagnoses was much lower (Any psychiatric diagnosis 8.5\% (6.9-10.5); Emotional disorder 2.0\% (1.2-3.0); Conduct disorder 6.6\% (5.1-8.3); Hyperactivity disorder $0.7 \%(0.3-1.4)$. These findings support greater investment in community and primary care prevention and treatment initiatives. ${ }^{4}$

In a systematic review of the non U.S. literature on interventions for students with behavioural disorders, it was found that the prevalence of behavioural and emotional problems is as high as $22 \%$ in the United States. These children have obvious difficulties that impact negatively on their lives, their families and their schools. ${ }^{5}$

India, a developing country has large population, of whom significant proportions are children attending school. Behavioral problems and psychiatric syndromes in the children are a matter of concern as the consequences can seriously impair their ability to become useful and productive citizens of tomorrow. The vulnerability of the child will increase when effective parenting is lacking. Children below 16 years of age constitute over $40 \%$ of India's population and estimating the prevalence of mental disorders in children and adolescents is critical to providing the mental health services they need. Psychiatric epidemiological studies from high-income countries indicate that more than a quarter of children and adolescents meet lifetime criteria for a mental disorder; and about $10 \%$ have distress or impairment that is severe enough to warrant intervention. Community studies on emotional/behavioural disorders in children and adolescents conducted in India have yielded disparate point prevalence estimates $(2.6 \%$ to $35.6 \%){ }^{6}$ An epidemiological study was done in Bangalore and Lucknow under the initiation of ICMR. The study was conducted on 2064 children from rural, urban and semi urban areas. The results indicated a prevalence rate of 12.5 percent among children aged 0-16 years. The prevalence rate in the 4-16 year old children was 12 percent. Enuresis, specific phobia, hyperkinetic disorders, stuttering and oppositional defiant disorder were the most frequent diagnoses. Physical abuse and parental mental disorder were significantly associated with psychiatric disorders. 
Life is challenging for children with emotional problems and it is also challenging for their families, their schools, and their teachers. These children often find it difficult to fit in with their peers and academic success often eludes them.

The literature review showed that several studies were conducted on emotional problems among school children from the western cultural set up. The number of such studies is less in our Indian cultural set up especially among Kerala population. The researcher felt the need for conducting a study to explore the socio-demographic correlates of emotional problems among school children, which could be helpful in seeking early interventions and adopting the preventive strategies.

\section{Statement of the problem:-}

A descriptive study to assess the socio-demographic correlates of emotional problems among school children in selected schools in Pathanamthitta District, Kerala.

Objectives of the study:-

- To assess the level of emotional problems among school children.

- To find out the association between emotional problems and selected baseline variables.

\section{Operational definition:-}

Emotional Problems:

In this study, emotional problems are the subjective conscious experience accompanied by physiological component and characterized by overt expressions and measured by Paediatric Symptom Checklist.

\section{Correlates:-}

In this study, correlates are defined as the factors which are mutually or reciprocally related to emotional problems among school children, including parental care, family background, socio-economic status, substance abuse, family psychopathology, life experiences, problem solving abilities, separation of significant persons etc, identified by baseline proforma.

\section{Assumptions:-}

- School children may have emotional problems which can affect their academic performance.

- Emotional problems among school children are multi-factorial.

\section{Materials and Methods:-}

A quantitative non experimental research approach with descriptive correlational design was adopted for this study. The study variable in the present study was emotional problems among school children. The baseline variables for the study were age, gender, religion, education, socio-economic status, type of family, area of residence, living with parents, emotional attachment, family history of psychiatric illness, suicide/attempt or alcohol/substance abuse, family situations, school situations, health problems, affected by recent death of near ones, spends time for pleasure/play/entertainment, use of alcohol/tobacco/cigarette/internet/other substances. The present study was conducted in selected schools of Elanthoor Block Panchayat, in Pathanamthitta District, Kerala. The target population for the study was school children studying in $8^{\text {th }}, 9^{\text {th }}$ and $10^{\text {th }}$ classes and the accessible population were school children studying in $8^{\text {th }}, 9^{\text {th }}$ and $10^{\text {th }}$ classes from selected schools of Elanthoor Block Panchayat, Pathanamthitta. Multistage cluster sampling technique was used in the study. The schools were selected randomly and the participants from these schools were selected using systematic random sampling technique. Study participants comprised of 500 school children between the ages of $13-15$ years. School children between the ages of $13-15$ years, studying in $8^{\text {th }}, 9^{\text {th }}$ and $10^{\text {th }}$ classes, who were present at the time of data collection, who can read and write Malayalam and who were willing to participate in the study were included in the study.

\section{Data collection tools:-}

The following tools were used for the study:

\section{- Baseline Proforma}

This tool consisted of 18 items to collect the baseline data regarding the participants age, gender, religion, educational level, socio-economic status, type of family, area of residence, living arrangements, parents' status, emotional attachment, family history of psychiatric illness, suicide/attempt or alcohol/substance abuse, family 
situations, school situations, jobs held, health problems, affected by recent deaths of near ones, spends time for pleasure/play/entertainment, use of alcohol/tobacco/cigarette/internet or other substances.

\section{- $\quad$ Paediatric Symptom Checklist Youth Self Report.(Y-PSC)}

It is a psychosocial screen designed to facilitate the recognition of cognitive, emotional and behavioral problems of children above 11 years, developed by Michael Jellinek and JM Murphy. The reported reliability of the tool $r=.89$. The Y-PSC consists of 35 items that are rated as "Never," "Sometimes" or "Often" present and scored 0" 1 and 2 respectively. The total score is calculated by adding together the score for each of the 35 items. For children and adolescents, ages 6 through 16 a cut off score of 28 or higher indicated psychological impairment.

\section{Validity and Reliability of the tools.}

The tools were given to 7 subject experts to get their consensus regarding the appropriateness of use of these tools in our setting. The content validity of the tools was established by the agreement of all seven experts. The tools were then translated to the vernacular language and it was retranslated to English and the reliability of the translated tools was assessed. The reliability of the tool was established by split half method using Spearman's Brown Prophecy formula. The calculated reliability of the tool was $r=0.83$, which was very closer to the established reliability.

\section{Pilot study:-}

The pilot study was conducted among 50 school children of Elanthoor Block Panchayat from 30/01/17 to 15/02/17. The study was found to be feasible and also no modifications were needed in the tool or methodology after the pilot study. Hence the researcher proceeded for the main study.

\section{Data collection process:-}

The main study was conducted among 500 school children studying in $8^{\text {th }}, 9^{\text {th }} \& 10^{\text {th }}$ class from selected schools, Elanthoor Block Panchayat, Pathanamthitta. After obtaining the ethical clearance from the Institutional Ethical Review Board and formal written permission from District Educational Officer, Pathanamthitta, the schools were selected randomly. The participants who fulfilled the inclusion criteria were selected by systematic random sampling. The data collection period was from 01/07/2017 to 30/09/2017. The participants were explained regarding the purpose of the study and an informed written assent was obtained from children and informed consent was obtained from parents. Confidentiality was assured to all the participants to get their cooperation. Proper instructions were given and the data collection was done by using self reporting technique. The participants were provided with the base line proforma and Y-PSC, and were asked to read each of the items carefully and fill the answers appropriately. It took $15-20$ minutes to complete the items. The obtained data were checked for completeness and coded for analysis.

\section{Plan for data analysis:-}

The data were organized, tabulated, summarized and analyzed using descriptive and inferential statistics. The prevalence of emotional problems among school children was calculated by using frequency and percentage of school children with emotional problems from the total number of school children screened for emotional problems. The association of baseline variables with emotional problems was done by Chi-square test.

Description of baseline variables of the school children:-

Table 1:- Distribution of school children according to age and gender

\begin{tabular}{|l|l|l|}
\hline VARIABLE & FREQUENCY & PERCENTAGE \\
\hline Age (in years) & & \\
\hline $13-15$ years & 500 & 100 \\
\hline Gender & & \\
\hline Male & 222 & 44.4 \\
\hline Female & 278 & 55.6 \\
\hline
\end{tabular}


Table 2:- Distribution of school children according to religion and level of education

\begin{tabular}{|l|l|l|}
\hline VARIABLES & FREQUENCY & PERCENTAGE \\
\hline Religion & & \\
\hline Hindu & 248 & 49.6 \\
\hline Christian & 238 & 47.6 \\
\hline Muslim & 14 & 2.8 \\
\hline Level of education & & \\
\hline $8^{\text {th }}$ standard & 165 & 33 \\
\hline $9^{\text {th }}$ standard & 155 & 31 \\
\hline $10^{\text {th }}$ standard & 180 & 36 \\
\hline
\end{tabular}

Table 3:-Distribution of school children according to socio economic status, type of family and place of residence

\begin{tabular}{|l|l|l|}
\hline \multicolumn{2}{|l|}{$(\mathbf{n = 5 0 0})$} \\
\hline VARIABLES & FREQUENCY & PERCENTAGE \\
\hline Socio-economic status & & \\
\hline Upper & 4 & 0.8 \\
\hline Upper middle & 73 & 14.6 \\
\hline Lower middle & 124 & 24.8 \\
\hline Lower lower & 299 & 59.8 \\
\hline Type of family & & \\
\hline Nuclear & 382 & 76.4 \\
\hline Joint & 93 & 18.6 \\
\hline Extended & 25 & 5 \\
\hline Place of residence & & \\
\hline Rural & 379 & 75.8 \\
\hline Urban & 61 & 12.2 \\
\hline Semi-urban & 60 & 12 \\
\hline
\end{tabular}

Table 4:- Distribution of school children according to living with whom, and parents' status

\begin{tabular}{|l|l|l|}
\hline VARIABLE & FREQUENCY & PERCENTAGE \\
\hline Living with & & \\
\hline Parents & 457 & 91.4 \\
\hline Single parent & 21 & 4.2 \\
\hline Relatives & 10 & 2 \\
\hline Friends & 7 & 1.4 \\
\hline Step parents & 4 & 0.8 \\
\hline Others & 1 & 0.2 \\
\hline Parents' status & & \\
\hline Living together & 478 & 95.6 \\
\hline Divorced & 12 & 2.4 \\
\hline Separated & 10 & 2 \\
\hline
\end{tabular}

Table 5:- Distribution of school children according to emotional attachment

\begin{tabular}{|l|l|l|}
\hline VARIABLES & FREQUENCY & PERCENTAGE \\
\hline Emotionally attached to: & & \\
\hline Father & 23 & 4.6 \\
\hline Mother & 61 & 12.2 \\
\hline Both parents & 394 & 78.8 \\
\hline Siblings & 6 & 1.2 \\
\hline Others & 8 & 1.6 \\
\hline None & 8 & 1.6 \\
\hline
\end{tabular}


Table 6:- Distribution of school children according to the presence of mental illness, suicide or suicide attempts, and alcohol/ substance abuse of relatives

\begin{tabular}{|l|l|l|}
\hline VARIABLES & FREQUENCY & PERCENTAGE \\
\hline Mental illness & 15 & 3 \\
\hline Suicide/ suicide attempts & 15 & 3 \\
\hline Alcohol/substance abuse & 64 & 12.8 \\
\hline
\end{tabular}

Table 7:- Distribution of school children according to the family situations

\begin{tabular}{|l|l|l|}
\hline VARIABLES & FREQUENCY & PERCENTAGE \\
\hline Over-protection by the parents & 358 & 71.6 \\
\hline Performs according to parental expectations & 393 & 78.6 \\
\hline Problems with parents & 30 & 6 \\
\hline Marital disharmony of parents & 35 & 7 \\
\hline Alcohol/ other substance abuse of a parent & 73 & 14.6 \\
\hline Over-strictness of parents & 90 & 18 \\
\hline Lacking in care -food/clothes/ love/health care & 8 & 1.6 \\
\hline Parental neglect & 31 & 6.2 \\
\hline Aggressive parent & 26 & 5.2 \\
\hline Early loss of a parent/ parents & 25 & 5 \\
\hline Unhealthy comparison with other children & 198 & 39.6 \\
\hline Problems with siblings & 45 & 9 \\
\hline Restricted socialization and play with peers & 73 & 14.6 \\
\hline Annoyed by parental authority & 132 & 26.4 \\
\hline Good family interactions & 429 & 85.8 \\
\hline Free to take decisions & 356 & 71.2 \\
\hline Childhood maltreatments & 14 & 2.8 \\
\hline Homelessness & 70 & 14 \\
\hline Family violence/ assault & 49 & 9.8 \\
\hline Frequent quarrels with relatives/ neighbours & 44 & 8.8 \\
\hline Verbal abuse & 23 & 4.6 \\
\hline
\end{tabular}

Table 8:- Distribution of school children according to personal factors and school situations

\begin{tabular}{|l|l|l|}
\hline VARIABLES & FREQUENCY & PERCENTAGE \\
\hline Personal factors: & & \\
\hline $\begin{array}{l}\text { Over-concern about one's own appearance/ } \\
\text { physique }\end{array}$ & 225 & 45 \\
\hline Worried about physical defects & 7 & 1.4 \\
\hline Health problems & 35 & 7 \\
\hline Spends time for pleasure/play/entertainment & 50 & 10 \\
\hline Feels guilty on any matters & 111 & 22.2 \\
\hline School situations & & \\
\hline Problems with friends/ classmates & 31 & 6.2 \\
\hline Problems with teachers & 25 & 5 \\
\hline Worried by teasing & 228 & 45.6 \\
\hline Copes well with studies & 426 & 85.2 \\
\hline Satisfied with academic performance & 205 & 41 \\
\hline Scholastic backwardness & 97 & 19.4 \\
\hline Truancy & 82 & 16.4 \\
\hline
\end{tabular}


Table 9:- Distribution of school children according to jobs held, recent death of near ones, sexual abuse, and use of substances

\begin{tabular}{|l|l|l|}
\hline VARIABLES & FREQUENCY & PERCENTAGE \\
\hline Jobs held & 27 & 5.4 \\
\hline Affected by recent death of near ones & 177 & 35.4 \\
\hline Sexual abuse & - & - \\
\hline Use of: & & \\
\hline Alcohol & 13 & 2.6 \\
\hline Tobacco & 5 & 1 \\
\hline Cigarette & 9 & 1.8 \\
\hline Internet (excessive use) & 163 & 32.6 \\
\hline Other substance use & - & - \\
\hline
\end{tabular}

Table 10:- Association of emotional problems with baseline variables of school children

\begin{tabular}{|l|c|l|l|}
\hline VARIABLES & Chi-square value & df & p value \\
\hline Age & 7.88 & 1 & $0.00^{* *}$ \\
\hline Gender & 0.73 & 1 & 0.39 \\
\hline Religion & 5.66 & 2 & 0.06 \\
\hline Level of education & 16.36 & 3 & $0.00^{* *}$ \\
\hline SES & 2.90 & 3 & 0.41 \\
\hline Type of family & 4.77 & 2 & 0.09 \\
\hline Place of residence & 2.80 & 2 & 0.25 \\
\hline Living with & 13.22 & 5 & $0.02^{*}$ \\
\hline Parents' status & 10.01 & 2 & $0.01^{*}$ \\
\hline Emotional attachment & 13.02 & 5 & $0.02^{*}$ \\
\hline Mental illness of relatives & 0.79 & 1 & 0.38 \\
\hline Suicide/ suicidal attempt of relatives & 0.50 & 1 & 0.48 \\
\hline Addiction of relatives & 1.17 & 1 & 0.28 \\
\hline
\end{tabular}

*- Significant at 0.05 level, **- Significant at 0.01 level, df- degrees of freedom

Table 11(a):- Association of emotional problems with baseline variables (family situations) of school children

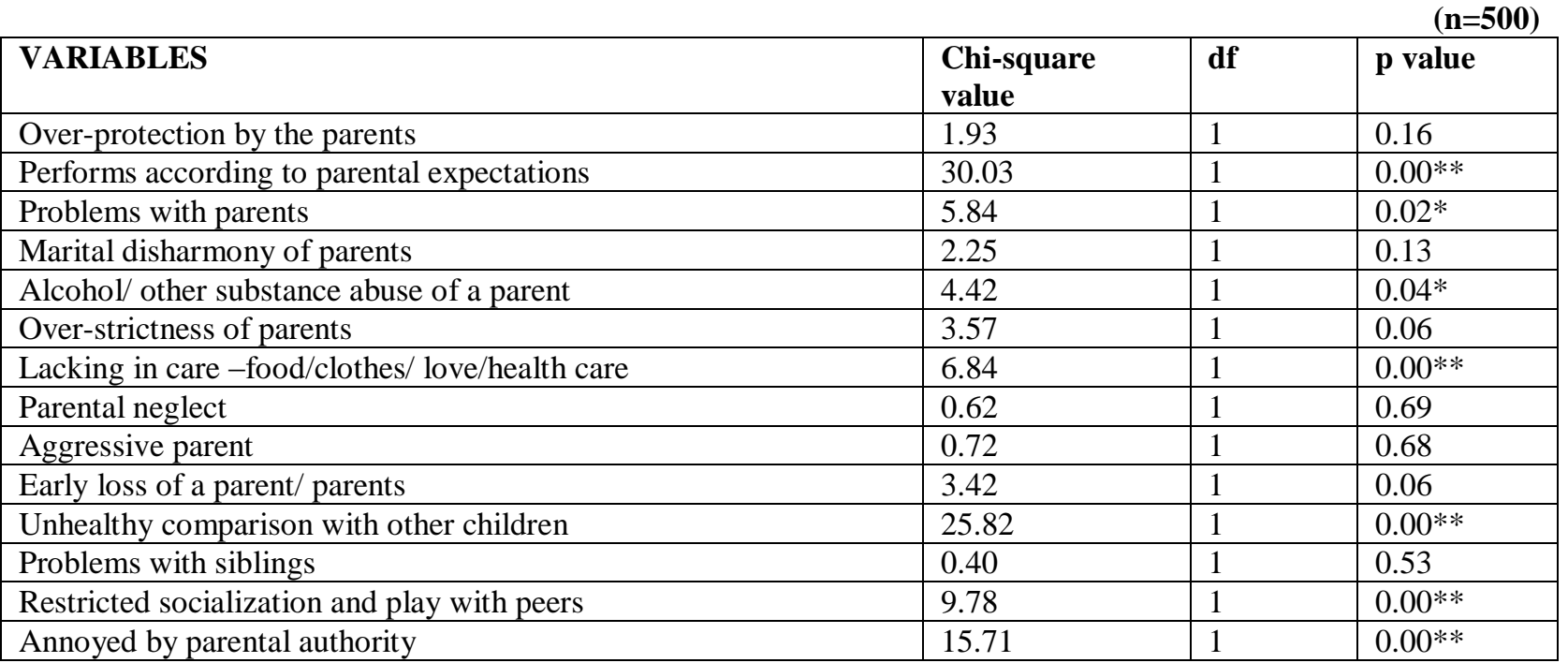

$*_{\text {- significant at } 0.05 \text { level }}$

**- significant at 0.01 level 
Table 11(b):- Association of emotional problems with baseline variables (family situations) of school children

$(\mathbf{n}=\mathbf{5 0 0})$

\begin{tabular}{|l|l|l|l|}
\hline VARIABLES & $\begin{array}{l}\text { Chi-square } \\
\text { value }\end{array}$ & df & p value \\
\hline Good family interactions & 9.75 & 1 & $0.00^{* *}$ \\
\hline Free to take decisions & 0.20 & 1 & 0.66 \\
\hline Childhood maltreatments & 2.88 & 1 & 0.09 \\
\hline Homelessness & 6.10 & 1 & $0.01^{*}$ \\
\hline Family violence/ assault & 2.63 & 1 & 0.11 \\
\hline Frequent quarrels with relatives/ neighbours & 7.26 & 1 & $0.00^{* *}$ \\
\hline Verbal abuse & 7.40 & 1 & $0.00^{* *}$ \\
\hline
\end{tabular}

*- significant at 0.05 level

**- significant at 0.01 level

Table 12:- Association of emotional problems with baseline variables (personal factors and school situations) of school children

\begin{tabular}{|l|l|l|l|}
\hline VARIABLES & $\begin{array}{l}\text { Chi-square } \\
\text { value }\end{array}$ & df & p value \\
\hline Personal factors & & & \\
\hline Over concern about physique & 4.05 & 1 & $0.04^{*}$ \\
\hline Physical defects & 0.00 & 1 & 0.97 \\
\hline Health problems & 13.18 & 1 & $0.00^{* *}$ \\
\hline Entertainment & 8.93 & 1 & $0.00^{* *}$ \\
\hline Guilty feeling & 55.39 & 1 & $0.00^{* *}$ \\
\hline School situations & & & $0.03^{*}$ \\
\hline Problems with Classmates & 4.94 & 1 & $0.00^{* *}$ \\
\hline Problems with teachers & 12.33 & 1 & $0.00^{* *}$ \\
\hline Worried about teasing & 14.28 & 1 & $0.00^{* *}$ \\
\hline Copes with studies & 18.29 & 1 & $0.00^{* *}$ \\
\hline Satisfied with academic performance & 25.62 & 1 & $0.00^{* *}$ \\
\hline $\begin{array}{l}\text { Scholastic backwardness } \\
\text { Truancy }\end{array} 38.42$ & 1 & $0.01^{*}$ \\
\hline
\end{tabular}

*- significant at 0.05 level;

**- significant at 0.01 level

Table 13:- Association of emotional problems with baseline variables (jobs held, recent death of near ones, sexual abuse and use of substances) of school children.

$(\mathbf{n}=\mathbf{5 0 0})$

\begin{tabular}{|l|l|l|l|}
\hline VARIABLES & Chi square value & df & p value \\
\hline Jobs held & 3.41 & 1 & 0.07 \\
\hline Recent death of near ones & 22.96 & 1 & $0.00^{* *}$ \\
\hline Sexual abuse & - & - & - \\
\hline Use of substances & & & \\
\hline Alcohol & 6.60 & 1 & $0.01^{*}$ \\
\hline Tobacco & 0.66 & 1 & 0.42 \\
\hline Cigarette & 2.25 & 1 & 0.13 \\
\hline Internet & 12.38 & 1 & $0.00^{* *}$ \\
\hline Others & - & - & - \\
\hline
\end{tabular}

*- significant at 0.05 level

**- significant at 0.01 level 


\section{Results:- \\ SECTION 1: DESCRIPTION OF THE BASELINE VARIABLES OF THE SCHOOL CHILDREN}

Baseline variables of the school children in the selected schools were computed using descriptive statistics, such as frequency and percentage.

All the subjects were in the age group of $13-15$ years i.e., $100 \%$ and $55.6 \%$ were females and $44.4 \%$ were males.

Majority of the respondents was Hindus (49.6\%). $47.6 \%$ were Christians, whereas only $2.8 \%$ were Muslims. $32 \%$ of school children were from $8^{\text {th }}$ standard, $31 \%$ from $9^{\text {th }}$ standard and $36 \%$ were from $10^{\text {th }}$ standard.

With regard to the socio-economic status, $59.8 \%$ of the school children belonged to lower- lower class, $24.8 \%$ belonged to lower middle class, $14.6 \%$ to upper middle class and $0.8 \%$ to upper class.

Majority of the school children (76.4\%) were from nuclear family. $18.6 \%$ belongs to joint family and $5 \%$ to extended family.

$75.8 \%$ of the school children were residing in rural area, $12.2 \%$ in urban area, and $12 \%$ in semi-urban area.

Most of the school children (91.4\%) were living with their parents. $4.2 \%$ of the subjects were living with single parent, $2 \%$ with their relatives, $1.4 \%$ with their friends, and $0.8 \%$ with step-parents.

$95.6 \%$ of the parents were living together along with the participants, $2.4 \%$ were separated, and $2 \%$ were widowed.

$78.8 \%$ of the school children had emotional attachment with both the parents. $12.2 \%$ of the school children were more emotionally attached with their mother. $4.6 \%$ were attached with fathers, $1.2 \%$ with siblings, and $1.6 \%$ with others such as relatives and friends. $1.6 \%$ of the school children were not at all attached to anyone.

$3 \%$ of the school children had relatives with a history of mental illness. $3 \%$ had a family history of suicide or suicide attempts and $12.8 \%$ had relatives who were addicted to alcohol or other substances.

Of the 500 school children, $71.6 \%$ experienced over-protection from their parents, $78.6 \%$ were able to perform according to the expectations of their parents, and $6 \%$ had experienced some sort of problems with their parents. $7 \%$ of parents of the school children had marital disharmony, and $14.6 \%$ of the parent(s) had alcohol or other substance abuse. $18 \%$ of school children reported that there was over-strictness in the family. $1.6 \%$ of school children were lacking care in basic needs and $6.2 \%$ reported parental neglect. $5.2 \%$ of the parents were aggressive, and 5\% of the school children had an early loss of parent(s). $39.6 \%$ of school children experienced unhealthy comparisons with other children, and 9\% experienced sibling rivalry or problems with the siblings. $14.6 \%$ of school children responded that they were restricted to have socialization and play with peers, and $26.4 \%$ were being annoyed by the parental authority. $85.8 \%$ had good family interactions, and $71.2 \%$ had the freedom to make decisions in the family. $2.8 \%$ of the adolescents experienced childhood maltreatments, and 14\% were living in rented houses. 9.8\% responded that there exists family violence/ assault, $8.8 \%$ had frequent quarrels with neighbours/ relatives, and $4.6 \%$ were exposed to verbal abuse in the family.

$45 \%$ of the school children were excessively concerned about their physical appearance or body image, $1.4 \%$ was worried about physical defects, and 7\% were having health problems (such as asthma, allergies, etc.). $10 \%$ of the school children were able to spend time for pleasure/ play/ entertainments. $22.2 \%$ were feeling guilty on matters like inability to perform according to the parent's expectations, getting angry to the parents/ friends/ siblings etc.

Of the 500 school children, $6.2 \%$ had problems with the friends or classmates, whereas $5 \%$ had problems with the teachers. $45.6 \%$ were worried by teasing. $85.2 \%$ were able to cope well with the studies and $41 \%$ were satisfied with the academic performance, whereas $19.4 \%$ had scholastic backwardness and $16.4 \%$ had truancy.

$5.4 \%$ of the school children held part-time jobs. $35.4 \%$ were affected by the recent death of near ones. None of the school children reported of being sexually abused. With regard to the substance use, alcohol was used by $2.6 \%$, tobacco by $1 \%$, cigarettes by $1.8 \%$ and excessive use of internet by $32.6 \%$. 


\section{SECTION 2: DESCRIPTION OF THE PREVALENCE OF EMOTIONAL PROBLEMS AMONG THE SCHOOL CHIDREN}

On the basis of the scores obtained in the Paediatric Symptom Checklist Youth Self - Report, 22\% were found to have scores suggestive of emotional problems and $78 \%$ were not having emotional problems.

\section{SECTION 3: DESCRIPTION OF RELATIONSHIP OF EMOTIONAL PROBLEMS WITH THE BASELINE VARIABLES OF THE ADOLESCENTS}

Association between the baseline variables and the level of emotional problems were computed using chi square test and binary logistic regression.

Chi square analysis showed a significant association between emotional problems and age $\left(\chi^{2}=7.88, \mathrm{df}=1, \mathrm{p}=0.00\right)$, level of education $\left(\chi^{2}=16.36, \mathrm{df}=3, \mathrm{p}=0.00\right)$, individuals with whom they are living $\left(\chi^{2}=13.22, \mathrm{~d} f=5, \mathrm{p}=0.02\right)$, parents living together or not $\left(\chi^{2}=10.01, \mathrm{df}=2, \mathrm{p}=0.01\right)$, emotional attachment $\left(\chi^{2}=13.02, \mathrm{df}=5, \mathrm{p}=0.02\right)$, performs according to parental expectations $\left(\chi^{2}=30.03, \mathrm{df}=1, \mathrm{p}=0.00\right)$, problems with parents $\left(\chi^{2}=5.84, \mathrm{df}=1, \mathrm{p}=0.02\right)$, alcohol/ other substance abuse of a parent $\left(\chi^{2}=4.42, \mathrm{df}=1, \mathrm{p}=0.04\right)$, lacking in care - food/clothes/ love/health care $\left(\chi^{2}=6.84, \mathrm{df}=1, \mathrm{p}=0.00\right)$, unhealthy comparison with other children $\left(\chi^{2}=25.82, \mathrm{df}=1, \mathrm{p}=0.00\right)$, restricted socialization and play with peers $\left(\chi^{2}=9.78, \mathrm{df}=1, \mathrm{p}=0.00\right)$, annoyed by parental authority $\left(\chi^{2}=15.71, \mathrm{df}=1, \mathrm{p}=0.00\right)$, good family interactions $\left(\chi^{2}=9.75, \mathrm{df}=1, \mathrm{p}=0.00\right)$, homelessness $\left(\chi^{2}=6.10, \mathrm{df}=1, \mathrm{p}=0.01\right)$, frequent quarrels with relatives/ neighbours $\left(\chi^{2}=7.26, \mathrm{df}=1, \mathrm{p}=0.00\right)$, verbal abuse $\left(\chi^{2}=7.40, \mathrm{df}=1, \mathrm{p}=0.00\right)$, over concern about physique $\left(\chi^{2}=4.05\right.$, $\mathrm{df}=1, \mathrm{p}=0.04)$, health problems $\left(\chi^{2}=13.18, \mathrm{df}=1, \mathrm{p}=0.00\right)$, entertainment $\left(\chi^{2}=8.93, \mathrm{df}=1, \mathrm{p}=0.00\right)$, guilty feeling $\left(\chi^{2}=55.39, \quad \mathrm{df}=1, \mathrm{p}=0.00\right), \quad$ problems with classmates $\left(\chi^{2}=4.94, \mathrm{df}=1, \mathrm{p}=0.03\right)$, problems with teachers $\left(\chi^{2}=12.33, \mathrm{df}=1, \mathrm{p}=0.00\right)$, worried about teasing $\left(\chi^{2}=14.28, \mathrm{df}=1, \mathrm{p}=0.00\right)$, copes with studies $\left(\chi^{2}=18.29, \mathrm{df}=1\right.$, $\mathrm{p}=0.00)$, satisfied with academic performance $\left(\chi^{2}=25.62, \mathrm{df}=1, \mathrm{p}=0.00\right)$, scholastic backwardness $\left(\chi^{2}=38.42, \mathrm{df}=1\right.$, $\mathrm{p}=0.00)$, truancy $\left(\chi^{2}=6.46, \mathrm{df}=1, \mathrm{p}=0.01\right)$, recent death of near ones $\left(\chi^{2}=22.96, \mathrm{df}=1, \mathrm{p}=0.00\right)$, alcohol use $\left(\chi^{2}=6.60\right.$, $\mathrm{df}=1, \mathrm{p}=0.01)$, and excessive use of internet $\left(\chi^{2}=12.38, \mathrm{df}=1, \mathrm{p}=0.00\right)$.

There was no significant association found between emotional problems and the baseline variables like gender, religion, socio economic status, type of family, place of residence, mental illness of relatives, suicide/ suicidal attempt of relatives, addiction of relatives, over-protection by the parents, marital disharmony of parents, overstrictness of parents, parental neglect, aggressive parent, early loss of a parent/ parents, problems with siblings, free to take decisions, childhood maltreatments, family violence/ assault, physical defects, jobs held, tobacco use, and cigarette smoking.

\section{Discussion:-}

The study conducted in selected schools of Elanthoor Block Panchayat, Pathanamthitta District, Kerala identified the existing prevalence of emotional problems and also its correlates among school children.

In this section we discuss: 1) the prevalence of emotional problems among school children; 2) the relationship of emotional problems with the baseline variables of school children.

\section{Prevalence of emotional problems among school children}

The results of the present study revealed that the prevalence of emotional problems among school children at Pathanamthitta district was $22 \%$. The findings also correspond to the results of studies conducted in Pakistan and Romania which has been reported a prevalence rate of $34.4 \%$ and $21 \%$ respectively. ${ }^{8}{ }^{9}$ The prevalence rate of emotional problems in this study was higher than that in other studies conducted in Malaysia, ${ }^{10} \mathrm{China}^{11}$ and Germany. ${ }^{12}$ These differences in the study results may be due to the differences in region, culture, use of different measurement tools, methods and different appraisal standards.

\section{Description of relationship of emotional problems with the baseline variables of school children}

In the present study, the researcher found a significant association between age and emotional problems $\left(\chi^{2}=7.88\right.$, $\mathrm{df}=1, \mathrm{p}<0.01$ ), with the highest prevalence of emotional problems at the age of $12-13$ years. A similar finding was obtained in a study conducted among school children in Maharashtra, where the behavioral problems were more prevalent in the age group of $12-13$ years and the age group of the study subjects was significantly associated with behavioral problems $(\mathrm{P}$ value $=0.004) .{ }^{13}$ The similarity in findings may be because school children at the age of 12 - 13 years have many physical, mental, emotional and social changes and they might be worried about these 
changes and how they are looked at by others. This is also a time that they might face peer pressure to use various addictive substances and they experience an increasing autonomy, and difficulties in social adjustments, predisposing them to emotional maladjustment.

The present study revealed no significant association between gender and emotional problems among school children. This may be because in the modern era of women empowerment, both males and females are treated equally in the families and societies. Girls are given more opportunities for flourishing in all fields, with adequate support, encouragement and guidance at every stages of development.

The present study revealed that there was no significant association between religion and emotional problems among school children $\left(\chi^{2}=5.66, \mathrm{df}=2, \mathrm{p}=0.06\right)$.

The class of study has got a significant association with $\left(\chi^{2}=16.36, \mathrm{df}=3, \mathrm{p}<0.01\right)$, with higher prevalence among students studying in $9^{\text {th }}$ standard. This may be because of the higher stress of studies and the psychosexual changes occurring in these age groups.

In the present study, it was found that socio-economic status of school children was not having association with the level of emotional problems.

According to the results of the present study, there was no significant association between the type of family and emotional problems among school children $\left(\chi^{2}=4.77, \mathrm{df}=2, \mathrm{p}=0.09\right)$ which was contradictory to various study results. A study was conducted to estimate the prevalence of psychiatric morbidity among school going children in local schools of Faridkot city in Punjab. There was a statistically significant difference in students having psychiatric illness living in nuclear families $(76.19 \%)$ as compared to the ones living in joint family set up. ${ }^{14}$ It can be due to lack of social virtues like co-operation, sympathy, sacrifice, affection, spirit of selfless service, obedience and broadmindedness and other advantage of joint family like social control.

The present study could not find any significant association between place of residence and emotional problems $\left(\chi^{2}=2.80, \mathrm{df}=2, \mathrm{p}=0.25\right)$

In the present study, there was significant association between the person with whom the school children are living and the level of emotional problems $\left(\chi^{2}=13.22, \mathrm{df}=5, \mathrm{p}<0.05\right)$. The findings also correspond to the results of the study done among secondary school students in Trinidad which has been reported statistically significant associations between depression and living arrangements $\left(\chi^{2}=12.12, \mathrm{df}=1, \mathrm{p}=0.01\right)^{15}$. The similarity in the findings may be because adolescents gain more emotional and intellectual growth when they live with their parents.

There was a statistically significant association between emotional problems and parents' status of living together or not $\left(\chi^{2}=10.01, \mathrm{df}=2, \mathrm{p}=0.01\right)$. The school children living with both the parents were less likely to be emotionally disturbed than those living with a single parent. This finding was supported by a study conducted among students of French schools. ${ }^{16}$ The similarity in the findings of the study may be attributed to the parents' belief that each one of them has got an equal role in the embodiment of their children.

Emotional attachment was found to be significantly associated with level of emotional problems $\left(\chi^{2}=13.02, \mathrm{df}=5\right.$, $\mathrm{p}=0.02$ ). A study done in Kenya reported that lack of emotional attachment with parents was significantly associated with emotional maladjustment. The co linearity between the results indicates that the school children spend more time with their parents for accomplishing their physical and emotional needs, irrespective of the differences in the culture.

According to the findings of the present study, emotional problems were not significantly associated with mental illness of relatives, suicide/ suicidal attempt of relatives, and addiction of relatives. The studies conducted in Saudi Arabia and Western Turkey demonstrated that these factors were having a significant association with emotional maladjustment among school children. The differences in the studies may be because of the decrease in influence of these factors in the present setting, as the majority of the participants were from nuclear families and the chances of interaction with relatives become occasional. 
In the present study, the factors which were found to have significant association with emotional problems were performs according to parental expectations $\left(\chi^{2}=30.03, \mathrm{df}=1, \mathrm{p}=0.00 ; \mathrm{OR}=3.38,95 \% \mathrm{CI}=2.16-5.30\right)$, problems with parents $\left(\chi^{2}=5.84, \mathrm{df}=1, \mathrm{p}=0.02 ; \mathrm{OR}=2.50,95 \% \mathrm{CI}=1.16-5.38\right)$, alcohol/ other substance abuse of a parent $\left(\chi^{2}=4.42, \mathrm{df}=1, \mathrm{p}=0.04 ; \mathrm{OR}=1.70,95 \% \mathrm{CI}=1.03-2.80\right)$, lacking in care - food/clothes/ love/health care $\left(\chi^{2}=6.84\right.$, $\mathrm{df}=1, \mathrm{p}=0.00 ; \mathrm{OR}=9.88,95 \% \mathrm{CI}=1.21-80.94)$, unhealthy comparison with other children $\left(\chi^{2}=25.82, \mathrm{df}=1, \mathrm{p}=\right.$ $0.00 ; \mathrm{OR}=2.58,95 \% \mathrm{CI}=1.78-3.73)$, restricted socialization and play with peers $\left(\chi^{2}=9.78, \mathrm{df}=1, \mathrm{p}=0.00 ; \mathrm{OR}=\right.$ $2.21,95 \% \mathrm{CI}=1.33-3.66)$, annoyed by parental authority $\left(\chi^{2}=15.71, \mathrm{df}=1, \mathrm{p}=0.00 ; \mathrm{OR}=2.25,95 \% \mathrm{CI}=1.50-3.36\right)$, good family interactions $\left(\chi^{2}=9.75, \mathrm{df}=1, \mathrm{p}=0.00 ; \mathrm{OR}=2.23,95 \% \mathrm{CI}=1.34-3.72\right)$, homelessness $\left(\chi^{2}=6.10, \mathrm{df}=1\right.$, $\mathrm{p}=0.01 ; \mathrm{OR}=1.89,95 \% \mathrm{CI}=1.13-3.14)$, frequent quarrels with relatives $/$ neighbors $\left(\chi^{2}=7.26, \mathrm{df}=1, \mathrm{p}=0.00 ; \mathrm{OR}=\right.$ $2.35,95 \% \mathrm{CI}=1.24-4.43)$, and verbal abuse $\left(\chi^{2}=7.40, \mathrm{df}=1, \mathrm{p}=0.00 ; \mathrm{OR}=3.31,1.34-8.19\right)$.

A cross-sectional study was conducted to estimate the prevalence of behavioral problems and related sociodemographic factors among secondary school children studying in $8^{\text {th }}$ and $9^{\text {th }}$ standard of both sexes in the municipal schools of a metropolitan city in India. The results revealed significant association $(\mathrm{p}<=0.01)$ between the behavioral problems of the study subjects and their age, gender, studying standard, studying language medium, type of family in which they were living, their ordinal position among their siblings, occupation of the father and alcohol consumption. ${ }^{17}$

A cross-sectional study was adopted to find out prevalence and factors associated with emotional and behavior problems amongst slum dwellers of 6 - 18 years of age in Miraj, Maharashtra. Study results revealed that children coming from families with over protective parental attitude were having high prevalence rate of behavioral problems which was statistically significant. The findings of the above mentioned studies explained the same variables mentioned in the present study as the risk factors for the development of emotional maladjustment among school children. $^{13}$

In the present study there was no significant association found between emotional problems and over-protection by the parents, marital disharmony of parents, over-strictness of parents, parental neglect, aggressive parent, early loss of a parent/ parents, problems with siblings, free to take decisions, childhood maltreatments, family violence/ assault. Even though these factors lacked statistical significance, it cannot be concluded that these could not influence emotional adjustment among school children.

In the present study, significant association was found between emotional problems and over-concern about physique $\left(\chi^{2}=4.05, \mathrm{df}=1, \mathrm{p}<0.05 ; \mathrm{OR}=1.44,95 \% \mathrm{CI}=1.01-2.06\right)$. No studies were available to compare the association between the emotional problems and over concern about the physique. A study conducted among Hong Kong adolescents indicated significant association between entertainment and emotional problems, similar to the present study $\left(\chi^{2}=8.93, \mathrm{df}=1, \mathrm{p}<0.01 ; \mathrm{OR}=2.45,95 \% \mathrm{CI}=1.34-4.47\right) .{ }^{18}$ This relationship may be explained as engaging in some hobbies moderates the effect of risk factors of emotional problems. In the present study, guilty feeling was found to be significantly associated with emotional problems $\left(\chi^{2}=55.39, \mathrm{df}=1, \mathrm{p}<0.01 ; \mathrm{OR}=5.38\right.$, $95 \% \mathrm{CI}=3.37-8.60)$. Worrying on physical defects was not found to be associated with emotional problems among school children.

In the present study, there was significant association between emotional problems and problems with classmates $\left(\chi^{2}=4.94, \mathrm{df}=1, \mathrm{p}<0.05 ; \mathrm{OR}=2.28,95 \% \mathrm{CI}=1.08-4.82, \mathrm{p}<0.05\right)$ and teachers $\left(\chi^{2}=12.33, \mathrm{df}=1, \mathrm{p}<0.01 ; \mathrm{OR}=\right.$ $4.67,95 \% \mathrm{CI}=1.83-11.90)$. In the present study, emotional problems was found to be associated with worried about teasing $\left(\chi^{2}=14.28, \mathrm{df}=1, \mathrm{p}<0.01 ; \mathrm{OR}=1.99,95 \% \mathrm{CI}=1.39-2.86\right)$ and ability to cope with studies $\left(\chi^{2}=18.29, \mathrm{df}=1\right.$, $\mathrm{p}<0.01 ; \mathrm{OR}=2.98,95 \% \mathrm{CI}=1.78-4.99)$. A study conducted among the adolescents in India reported significant association between inability to cope with studies and emotional problems $(\mathrm{p}=0.01)$, whereas lack of association between teasing and emotional problems. ${ }^{19}$ The present study obtained significant association between scholastic backwardness $\left(\chi^{2}=38.42, \mathrm{df}=1, \mathrm{p}<0.01 ; \mathrm{OR}=4.26,95 \% \mathrm{CI}=2.64-6.89\right)$ and truancy $\left(\chi^{2}=6.46, \mathrm{df}=1, \mathrm{p}<0.01 ; \mathrm{OR}=\right.$ $1.85,95 \% \mathrm{CI}=1.15-2.98)$ and emotional problems. Satisfaction with academic performance was found to be a protective factor in the present study, that moderates emotional stability $\left(\chi^{2}=25.62, \mathrm{df}=1, \mathrm{p}<0.01 ; \mathrm{OR}=0.39\right.$, $95 \% \mathrm{CI}=0.27-0.57)$. The similarity in the findings may be attributed to the fact that the society places high priority on academic achievement, especially in the patriarchal culture, which creates undue mental burden to the school going children. 
The study found statistically significant association between recent death of near ones and emotional problems $\left(\chi^{2}=22.96 ; \mathrm{df}=1 ; \mathrm{p}<0.01\right)$. Logistic regression analysis suggests that recent death of near ones contributes to development of emotional problems by 2.48 times when compared with those who have not experienced recent death of near ones $(\mathrm{OR}=2.48 ; 95 \% \mathrm{CI}=1.70-3.61 ; \mathrm{p}<0.01)$. This result is in accordance with a study conducted in Saudi Arabia, which points out significant association between history of relative loss and emotional problems among school children. ${ }^{20}$ The similarity of the findings indicates that death of near ones can adversely affect the psychological well-being of the children, irrespective of their culture or nationality.

In the present study, alcohol use was found to be significantly associated with emotional problems among school children $\left(\chi^{2}=6.60, \mathrm{p}<0.05 ; \mathrm{OR}=4.74,95 \% \mathrm{CI}=1.29-17.45, \mathrm{p}<0.05\right)$. Studies conducted among school children in India $(\mathrm{p}<0.05)$ and Trinidad $\left(\chi^{2}=20.82, \mathrm{df}=1, \mathrm{p}<0.01\right)$ identified significant associations between alcohol use and emotional problems. ${ }^{13}$ The similarity between the findings indicates that alcohol use predisposes the development of emotional problems among school children.

Excessive use of internet was found to be significantly associated with emotional problems $\left(\chi^{2}=12.38, \mathrm{p}<0.01\right.$; $\mathrm{OR}=1.97,95 \% \mathrm{CI}=1.35-2.28, \mathrm{p}<0.01)$. A study done among the Korean adolescents revealed significant relationship between problematic internet use and adolescent depression. ${ }^{21}$ The similarity of the findings may be due to the increasing addiction of the school children to the social networking media, which hinders them from using time for productive works and effective ways of coping with the psychological distresses.

\section{Conclusion:-}

In the present study the prevalence of emotional problems among school children was estimated as $22 \%$ and it was influenced by several factors. Significant association was found between the emotional problems of the study subjects and their age, educational level, person with whom the subjects are living, parents status of living together, emotional attachment of the subjects, able to perform according to parent's expectations, good family interactions, substance abuse of parents, problems with parents, lacking in basic needs, unhealthy comparison with other children, restricted socialization, annoyed by parental authority, frequent quarrels and verbal abuse. School environment, recent death of near ones, use of alcohol and excessive use of internet were also found to be significantly associated with emotional problems of school children.

The public health significance of this study is that it provides a conceptual frame work for addressing mental health promotion goals and also provides suggestions for school - based mental health activities, thereby bringing a holistic development among the children, who will be the future of the nation.

Ethical approval: The study was approved by the Institutional Ethics committee.

\section{Acknowledgements:-}

With profound joy and gratitude, the researcher expresses sincere and deep sense of gratitude to supervising guide, Dr. Mridula Saikia Khanikor Principal, Vinayaka Mission Sikkim College of Nursing for her sustained enthusiasm, creative suggestions, motivation and exemplary guidance throughout the course of my research work. Researcher also acknowledges the help of those who have been involved in the successful completion of this endeavor. Researcher expresses her deep sense of gratitude to District Educational Officer, Pathanamthitta District, Kerala and the Principals of the schools for granting permission to conduct the study. The author also appreciates all those who participated in the study and helped to facilitate the research process.

e) Conflict of interest:Nil.

Funding Sources: No funding sources 


\section{References:-}

1. Linda RA, Richardson. L. (2006): School based prevention and intervention programs for children with emotional disturbance. Education and Treatment of Children. 29(2): 379 - 404.

2. National Survey of Children's Health. (2003): In Statistics US Department of Health and Human Services. Center for Disease Control and Prevention, editor.

3. Elhamid AA , Howe A \& Reading R. (2009): Prevalence of emotional and behavioural problems among 6-12 year old children in Egypt. Soc Psychiatry Psychiatr Epidemiol. 44(1): 8-14.

4. Daniel J, Lopes A. (2007): Interventions for Students With Behavioral Disorders: An International Literature Review. Behavioral Disorders. 32(4): 267-81.

5. Nandi DN BG, Mukherjee SP, Ghosh A, Nandi PS, Nandi S. (2000): Psychiatric morbidity of a rural Indian community. Changes over a 20-year interval. Br J Psychiatry. 176: 351 - 6.

6. Shoba Srinath, Shekhar Seshadri, Narender Kumar. (2005): Epidemiological study of child \& adolescent psychiatric disorders in urban and rural areas of Bangalore, India. Indian Journal of Medical Research: 67 - 79.

7. Syed EU Hussiein S A, Haidry S. (2009): Prevalence of Emotional and Behavioral Problems Among Primary School Children in Karachi, Pakistan - Multi Informant Survey. Indian Journal of Pediatrics. 76 (June): 623 -7.

8. Ramona Buzgar \&, Adrian Opre. (2013): Emotional and Social Problems in Primary School Children: a National Screening Program. Social and Behavioral Sciences. 78: 250 - 4.

9. Idris, Idau B. (2013): A longitudinal study of emotional and behavioral problems among Malaysian school children with a nested evaluation of a parenting programme.

10. Liu X Kunitha H, Sun Z \& Wang F. (1999): Risk factors for psychopathology among Chinese children. Psychiatry and Neuroscience. 53: 497 - 503.

11. Claus Barkmann \& Markwort M S. (2005): Emotional and behavioral problems of children and adolescents in Germany: An epidemiological screening. Soc Psychiatry Psychiatr Epidemiol. 40: 357 - 66.

12. Naik JD \& Jogdand S. (2013): Socio-demograohic Correlates of Behavior Problems amonst the Urban Slum Dwellers Aged between 6 to 18 Years. National Journal of Medical Research. 3(3): 222 - 5.

13. Kaur S Thapar S K \& Shandilya V. (2015): The prevalance of psychiatric morbidity among school children. International Journal of Medical and Dental Sciences. 4(2): 834 -41.

14. Maharaj R G, et al. (2008): Depression among adolescents, aged 13 - 19 years, attending secondary schools in Trinidad prevalence and associated factors [database on the Internet] [cited 2014 Jan 20].

15. Costello E J , Mustillo S , Erkanli A \& Angold A. (2003): Prevalence and development of psychiatric disorders in childhood and adolsence. Archives of General Psychiatry. 60(8): 837-44.

16. Masare M S , Bansode-Gokhe S S \& Shinde R R. (2017): A cross sectional study of behavioral problems of secondary school children and related socio-demographic factors. International journal of Research in Medical Sciences. 5(6): 2760 - 6.

17. Lalu M \& Khan M . (2010): Prevalence and correlates of problem behaviors among adolescents in Hong Kong. Asia-Pacific Journal of Public Health. 22(3): $354-64$.

18. Rama Rao K T \& Raju M. (2013): Early Adolescents: Emotional and Behavioral Problems. Journal of the Indian Academy of Applied Psychology. 38(1): 34 -9.

19. Abden-Fattah M M , Assan Al-Jabal T M \& Arafa M A. (2004): Emotional and Behavioural Problems among male Saudi school children and adolescence prevalence and risk factors. German Journal of Psychiatry. 1:1-9.

20. Park S , Hong K E , Park E J et al. (2013): Association between problematic internet use and depression, suicidal ideation and bipolar depressive symptoms Korian adolescents. The Australian \& New Zealand Journal of Psychiatry. 47(2): 153-9. 